\title{
Honcz Imola
}

\section{Utazás és késô modern identıtáskonstrukció}

\author{
Hátızsákos utazók élményeı
}

\section{Bevezetés}

A fogyasztás, a szabadidő-eltöltés, minthogy meghatározó részévé váltak életünknek, az egyén identitáskonstrukciójában, önmeghatározásában, a társadalomban elfoglalt helyének definiálásában jelentős szerepet játszhatnak. A szabadidős utazás egy ilyen funkcióval bíró területként jelenik meg ebben az írásban, lehetséges motivációinak és hatásainak számbavételével. Talán feltűnő jelenség napjainkban az utazással kapcsolatban, hogy hazánkban, hazánkból is egyre többen indulnak útnak egy szál hátizsákkal, és saját tempóban, saját érdeklödéstől hajtva néznek körül más tájakon. Jelen tanulmány célja felvázolni, hogy milyen élethelyzetben lévők szánják rá magukat erre a lépésre, és elsősorban a késő modernitás Anthony Giddens-i elméletéből kiindulva megkísérelni azt is megválaszolni, hogy vajon mennyiben tekinthető a hátizsákos utazás ontológiai biztonságot és identitáskonstrukciót érintő problémákat enyhíteni képes tevékenységnek. Másképp fogalmazva: egy bizonytalan világban segíthetnek-e az utazás bizonytalan keretei a biztonság megtalálásában. Ennek megválaszolásához félig strukturált életútinterjúk elemzése vezet majd, a kiinduló élethelyzet, az utazó által megélt élmények és ennek nyomán a benne lejátszódó változások dinamikájának felfejtése által.

\section{A (szervezett) utazás jelensége napjainkban társadalomtudományi nézőpontból}

Az idegenforgalom a világgazdaság meghatározó tényezőjévé nőtte ki magát, a kortárs világ összetett társadalmi-kulturális-gazdasági jelenségévé vált. Az utazás története szorosan összekapcsolódik a fokozatosan intézményesülő turizmus történetével. Az utazás demokratizálódása (Urry 2002) egyre szélesebb rétegek számára tette lehetővé ezt a tevékenységet, a turistaként való cselekvést, ami így a modern ember élettapasztalatának szerves részévé 
vált. ${ }^{1}$ A globalizáció, a térbeli mobilitás mindennapivá válása nyomán a társadalomtudományok fogalomkészletében is megjelentek a turista, az utazás, az áramlás metaforái, a késő modern, szabadidő-központú fogyasztói társadalom viszonyai ideiglenességének megragadására (Bódi 2008), valamint a fejlett országok társadalmának makroszerkezetét konstruáló erőviszonyok leírására (lásd Bauman 2002, 2004).

Scott Lash és John Urry (1994) elmélete szerint a szervezett kapitalizmus utáni rend intézményi struktúrája nem nemzetállami keretek között szerveződik, hanem lényegessé válnak a globális „áramlások”, értve ezalatt a tőke, a termelés, a fogyasztás és az információk felfokozott áramlását is, ami alapvetően felgyorsítja az élet tempóját. Mindez a turizmust tekintve fokozottan érvényes tendencia, hiszen emberek helyváltoztatásával egyidejűleg tőke, fogyasztás, információ és kultúra is mozgásba lendül. ${ }^{2}$ Zygmunt Bauman (2002) értelmezésében a globalizáció szorosan kapcsolódik a turisták álmaihoz és vágyaihoz. Korunk fogyasztói világát ő is nyugtalannak írja le, amelyben a mozgásban levés jelenti a boldogságot, hiszen közben fogyasztani lehet, látszólag szabad akaratunk szerint, ugyanakkor döntéseinket társadalmi kényszerek is befolyásolják. Egy utazás során elsősorban érzéseket, korábban még nem tapasztalt új élményeket szeretnénk, illetve „kell” gyüjteni. Urry (2002) értelmezésében is azért kel útra az ember, a turista, hogy időlegesen elszakadhasson a mindennapi élet gyakorlatától, a bevett rutinoktól, és ismeretlen ingereknek tegye ki magát.

A fejlett országok társadalmának életét tehát nagymértékben áthatja az élmények keresésének szándéka, az utazás pedig, ideiglenessége és a megszokottól eltérő jellege miatt is, intenzív élményszerzési időszak. Gerhard Schulze (2000; 2003) kifejti, ${ }^{3}$ hogy míg a szűkösség társadalmában az egyén cselekvési lehetőségeit a megélhetés problémája korlátozta, addig az élménytársadalomban az életkörülmények javulása az élet valamennyi területén a lehetőségek közötti választás szabadságát és egyben kényszerét hozta el, mely az élet megélésének módjára, annak széppé és értelmessé tételére összpontosítja a figyelmet. Már nem csak a munka utáni szórakozásra szorítkozva, hanem a hétköznapi cselekvésekben is elsődleges preferenciává vált az élmény, és ezáltal a boldogság keresése. Schulze (2000) elméletében a kívülről jövő hatás, egy esemény csak feldolgozva válik élménnyé, tehát elsődlegesek az egyén egyedi belső, integráló, átalakító, értelmező szubjektív folyamatai (Éber 2008). A szubjektum eszerint az önmegvalósítást többek között a hétköznapi élet bármely, pozitívként megélt, azaz szép élményének átélésében és az arra való reflexióban teljesíti ki. Az egyén önazonosságának legmeghatározóbb elemévé a kulturális fogyasztás, az élményszerzés módja válik, melyek a társadalmi világ tagozódásában is központi szerepet játszanak Schulze (2000) szerint. ${ }^{4}$

1 Kutatása ebből kifolyólag is fontos, és mint nem mindennapos tevékenység, az attól való eltérés vizsgálata segíthet megérteni a „normál” társadalmi gyakorlatokat is (Urry 2002).

2 „A turizmus többé [...] nem a modern nemzeti lét mellékes és múló rituáléja, hanem a transznacionális modern életet szervezö jelentös körülmény” (Franklin és Crang 2012: 147), amelynek az emberek többsége alkalmanként bizonyos mértékben részesévé válik a mindennapjai során a turistákkal való találkozás és a nekik kialakított látványos és szórakoztató terek használata által (Franklin és Crang 2012).

3 Bár sok kritika érte amiatt, hogy látszólag nem vesz tudomást számos társadalmi problémáról és csoportról, véleménye szerint az árnyoldal mellett létező gyarapodás és megnövekedett lehetőségek is ugyanolyan realitások, melyek vizsgálata nem tagadja a szükösség problémáit (Éber 2008).

4 A korábbi mereven hierarchikus szerkezet helyett most az egyének hasonló életstílus, kor és képzettség, valamint a sűrűbb belső kommunikáció és a hasonló információfeldolgozás mentén szerveződő, egymásba mosódó miliőkbe csoportosíthatók (Schulze 2000; Éber 2008). 
Lash és Urry (1994) is kiemelik az „esztétikai alapú fogyasztói logika” (Sik 2013c: 10), az „esztétikai reflexió” egyre fontosabbá válását, ami esetükben azt jelenti, hogy olyan cselekvési tér rajzolódik ki - a szolgáltatói, fogyasztói terepen -, ahol a döntések szubjektív ítéletek, tetszés alapján, hosszas racionális mérlegelés nélkül születhetnek, mintegy az eldologiasító rendszerektől elvonatkoztatva, egyfajta autonóm felfedezés által (Sik 2014). Az a lehetőség tehát, hogy az utazás által a rutinoktól próbál menekülni olykor az egyén, Lash és Urry (1994) szerint pontosan az esztétikai reflexiónak nyit teret:

Az utazások [...] a reflexió kitüntetett pillanataiként funkcionálnak. Olyan időtöltésként, melynek elsődleges funkciója más világok és ezáltal a saját világra történő esztétikai reflexió. Ebben az értelemben az identitáskonstrukció folyamatának és a reflexiós kompetenciák elsajátításának egyaránt központi terepei lettek (Sik 2013c: 18). ${ }^{5}$

\section{A késő modern identitáskonstrukció általános kihívásai és az utazás lehetséges hatásai, funkciói}

A schulzei (Schulze 2000; Éber 2008) élménytársadalomban a cselekvési lehetőségek bővülése az értelemképző választás szabadsága mellett a döntéshelyzetből fakadó bizonytalanságot is magában hordja, amely határozatképtelenség esetén szorongáshoz vezet. Ez az egyéniséget kibontakoztató esztétikai szempontok és a valahová tartozást kifejező közösségi minták szerinti választással ellensúlyozható, ugyanakkor az unalom és kiábrándulás kockázatát növeli azáltal, hogy a szubjektum hozzászokik az élmények ingereihez, vagy tudja, hogy más lehetőségek potenciálisan jobb élményéről mond le, ha valamit választ. Az élményorientált létezésben tehát jórészt efféle kettős problémával küzd az egyén (Schulze 2000; Éber 2008). Az utazás ebben az értelmezési keretben a mindennapok egy epizódjaként tünik fel, amely lényegében - az omniprezens élményorientáltságból fakadóan - nem különbözik más tevékenységektől, ám ugyanúgy lehetőséget teremt az életfeladattá váló önkifejezésre és az élet értelmessé tételére.

A giddensi teória szerint az egyén legalapvetőbb egzisztenciális igénye a tudat alatti vágyból fakadó ontológiai biztonság megteremtése. Az ontológiai biztonság „azt fejezi ki, hogy otthonosan érzi-e magát a börében a cselekvö, belakja-e a rendszeresen elöforduló helyzeteket és neki jutó szerepeket” (Sik 2013b: 57), valamint képes-e „eligazodni társadalmi világában, amelyben tudja saját helyét is" (Berger 2013: 31). A hétköznapi cselekvési rutinok és a rutinizált személyközi viszonyok tudat alatt ennek létrehozásáért alakulnak ki, kiszámíthatóvá, otthonossá téve a különböző élethelyzeteket. ${ }^{6}$ A döntésképtelenség a schulzei elképzeléshez képest kevésbé könnyen feloldható válságnak tünik Anthony Giddens vagy akár Ulrich Beck kordiagnózisából kiindulva. „Az élethelyzetek és életutak diverzifikálódása és individualizálódása” (Beck 2004: 323) a privát szféra nagyobb döntési szabadsága mellett

5 Sik Domonkos idézésénél oldalszámot nem tüntetek fel, mert írása egybefüggően jelent meg az irodalomjegyzékben megadott honlapon, ezért a bekezdés számát adtam meg.

$6 \mathrm{Az}$ ontológiai biztonság és az én megjelenítése föként a test szabályozásának autonómiájában élhető át (Sik 2013b; 2013a), így a bizonytalanságok és szorongások elsősorban testi zavarokban nyilvánulnak meg, nem csak a reflexió szintjén (Sik 2013a). A szokások pedig könnyen kényszeres viselkedésbe, neurózisba csaphatnak át parancsoló erejük elfajulása miatt (Giddens 2013: 91). 
azt is magával hozta, hogy az egyének a hagyományos struktúrák, szerepek, gondoskodási formák felbomlása és a társadalmi meghatározottságokból való viszonylagos kiágyazódás miatt magukra maradtak a felmerülö kockázatokkal, kételyekkel szemben. Ezeket kollektíven megoldandó problémák helyett a személyes sors feldolgozandó kudarcaiként, egyedül élik meg, szorongás, büntudat kíséretében.

A hagyományhoz való kapcsolódás, erkölcsi jellege folytán, ontológiai biztonságot, lelki támaszt nyújt, viszont a késő modernitásban a megkérdőjelezhetetlennek gondolt alapelvek, viszonyítási pontok fellazulása miatt az önazonosság felépítése és az ontológiai biztonság fenntartása problematikussá, egyéni reflexív projektté válik (Giddens 2013), amelyben a hibák elkövetése ${ }^{7}$ az identitás egészét kérdőjelezi meg a helytelen kockázatbecslés és reflexiós munkából fakadó szégyenérzet okán (Sik 2013a). A koherens identitás kialakítását tehát a szorongás és szégyenérzet elkerülése, valamint az ontológiai biztonság megélésének vágya hajtja, és a mindennapi döntési és választási helyzetekre adott válaszok szervezik egységes keretbe (Sik 2013a). Az ontológiai biztonságnak ugyanakkor a saját énnel kialakult harmonikus kapcsolat mellett a másokkal folytatott interakció kiegyensúlyozottsága is elöfeltétele. Ezek rutinszerűvé tétele erősíti a bizalmat és az otthonosság érzését (Sik 2013b). A városok lazább ismeretségi és szomszédsági viszonyaiban (Beck 2004), az egzisztenciális szorongással jellemezhető (Sik 2013a) személytelen kapcsolatokban viszont nehéz feladatnak tünik a személyesség kialakítása. A személyes, intim kapcsolatok ugyanakkor jelentősek az én egységként való elismerése és az önábrázolás lehetősége (Luhmann 1982) mellett azért is, mert elsődleges, kiemelt terepei lettek „közvetlenül az identitáskonstrukciónak, közvetve pedig az ontológiai biztonság megteremtésének, valamint a reflexivitásnak” (Sik 2013a: 131).

Az utazás ez utóbbi értelmezési keretben az élménytársadalmihoz képest kivételesebb gyakorlatnak tekinthető. A rutinok Lash és Urry nyomán eddig olyan cselekvésmintázatokként tüntek fel a turizmust tekintve, melyektől való szabadulás az utazás egyik motivációja lehet. Giddens elméletében központi szerepet töltenek be az ontológiai biztonság megteremtése szempontjából, ugyanakkor a cselekvők reflexivitása miatt a változtatás igénye is felmerülhet bennük (Rényi, Sik és Takács 2014), sőt a rutinokba való kapaszkodás patologikus hatásokkal is járhat. Ennélfogva az utazás a rutinokat megújító mozzanatként is értelmezhető, egyrészt azokon konkrétan módosítva, vagy másrészt akár ugyanazokat a rutinokat egy másik lokális kontextusba áthelyezve is ki lehet próbálni, amivel a távoli helyek is ismerőssé válhatnak. Emellett elképzelhető az is, hogy az utazás mégiscsak a túlzottan kiszámítható rutinok felfüggesztése, ám ennek ismétlése szintén lehet rutin, „rutinná vált nem rutin” (Urry 2002: 11). Az utazás során továbbá könnyen előfordulhat, hogy a különféle emberekhez való hozzáállást nem, vagy kevésbé terhelik az otthoni ontológiai bizonytalanság kételyei, és így az utazó egyén ugyan általában nem hosszú távú, de mégis intim, tiszta (lásd Giddens 2005) kapcsolatok kialakítására is törekedhet, ami által lehetőség nyílhat az esetleg megkérdőjelezett, elveszett otthonosság, identitás, valóságértelmezés újrateremtésére, az ontológiai biztonság helyreállítására is.

7 Problémák esetén a rutinszerüség megszakadása az ontológiai otthonosságot felfüggeszti, és reflexió tárgyává teszi az addig természetesnek tekintett gyakorlatokat (Sik 2013b; Berger 2013). 


\section{A hátizsákos utazás, a hátizsákos utazók}

A modern hátizsákos utazás történelmi gyökerei feltehetően egyrészt a Grand Tour, az arisztokrata fiatalok európai körútjaiban, másrészt pedig az alsó társadalmi osztályokhoz tartozók, például az iparoslegények munka reményében történő vándorlásában kereshetők. Mindez arra utal, hogy ez a kulturális szokás egyfelől felülről, másfelől - és főként - alulról is formálódott, ami részben megmagyarázza korunk hátizsákos utazóinak heterogenitását (Cohen 2004; Noy 2015). A 20. században a nyugati középosztály megerősödése és annak ellenkulturális sajátosságai útjára indítottak számos fiatalt, akik arra vágytak, hogy a konvencionálistól eltérő - az elképzeléseiknek megfelelően akár „primitívnek” is mondható - környezetben éljenek. Így tehát egy másik fontos előzménye a nomád, hátizsákos turizmusnak a hippi kultúra, amelyben az értelmes és autentikus kulturális lét keresésével erősen keveredett a spirituális megvilágosodás iránti vágy és a drogkultúra (Ateljevic és Doorne 2004).

A fogyasztás dominanciájával párhuzamosan, a turizmus exponenciálisnak mondható növekedésével egyidejüleg a hátizsákos utazás is egyre láthatóbbá, ${ }^{8}$ intézményesebbé, sokszínűségével és egyúttal megkülönböztető jellegzetességeivel a turizmus egy nagyon szegmentált, gyorsan változó alkategóriájává nőtte ki magát (Noy 2015). A hippi vándor képe ${ }^{9}$ helyére a költségvetés-orientált független utazó lépett, akit már nem a '60-as, '70-es évek ellenkultúrájának forradalmi eszméi indítanak útnak, hanem leginkább az egyéni változás vágya vagy az élménykeresés. Napjainkban a technológiai-gazdasági változások széles körben elérhetővé tették ezt a fajta utazást, így a hátizsákos utazók között mindenféle társadalmi helyzetü, korú, valamint politikai meggyőződésü embert találunk. Egyes szerzők szerint nem általában véve a társadalommal, hanem inkább a tömegturizmussal szemben vannak aggályaik (O’Reilly 2006).

Bár a szakirodalom igen változatos a jelenség meghatározását illetően, a közös pontot az adja, hogy a hátizsákos utazók olyan nem intézményesített keretek között utazó turistacsoportot alkotnak, amely egyértelmüen elkülöníthető az intézményesített tömegturizmustól (Cohen 1972; Vogt 1976; Riley 1988). A nem intézményesített turizmus a turizmusiparral minimális kapcsolatot létesítő egyéni utazásokat jelenti, a benne részt vevőket pedig inkább jellemzi a nyitottság az újdonságok iránt, a kockázatvállalás, a spontaneitás (lásd Cohen 1972; Puczkó és Rátz 2001). A hátizsákos utazás szakirodalomban is rögzített formai, külső jellemzői a hosszabb időtartamú, egyénileg szervezett utazás, a rugalmas útiterv és időbeosztás, az alacsony költségvetés, az olcsó éttermekben étkezés, a tömegközlekedés használata és a drága hotelszobák bérlésének kerülése, a személyes kapcsolat keresése más utazókkal és a helyiekkel (Cohen 1972; Vogt 1976; Riley 1988).

Annak dacára ugyanakkor, hogy a tömegturizmushoz hasonlóan a hátizsákos utazás egyes útvonalai, szokásai bejáratottan, szervezetten, egyes szerzők (Cohen 2004) szemében

8 Ennek növekedését pontos adatokkal nem igazán lehet szemléltetni, mivel az egyes régiók, országok statisztikái nem rögzítik célzottan a hátizsákos turizmus adatait, kivéve például Ausztráliát. Az ifjúsági turizmus jelentőségteljes növekedése viszont jó mutatója lehet a hátizsákos turizmus növekvő arányának, mivel ez az utazási forma népszerü a fiatalok körében (O’Reilly 2006), persze még így is eltörpül a tömegturizmus volumenéhez képest.

9 A hippi vándor a hátizsákos utazó mintaképeként, archetípusaként értelmezhető (Cohen 2004), ám nem feleltethető meg azzal már csak azért sem, mert ahogyan a hátizsákos utazók a sztereotip turistáktól szeretnének távolságot tartani, úgy vannak olyan vándorok, akik ugyanígy gondolnak az eltömegesedő hátizsákos utazókra, főként a fiatal, bulizni vágyókra (Welk 2004), amely elhatárolódás az identitás kialakításának, az önmeghatározásnak egy eleme lehet. 
akár elcsépeltnek nevezhetően zajlanak, egy nagyon összetett jelenség, és az utazók számára az élmény jelentősége nem csökkent (O’Reilly 2006). A hátizsákos utazók - az utazás számától és az életkortól független - legfőbb motivációjának a más kultúrák megismerése, a saját tudás bővítése, a helyiekkel való interakció és a lazítás tủnik. A személyes/társas fejlödés (pl. képességek gyakorlása, barátságok kötése, önmegismerés), az autentikus, intenzív valódi tapasztalás (pl. életre szóló új élmények, izgalom), a függetlenség (önálló utazásszervezés, járatlan utak, szabadnak és nyitottnak lenni), a minél olcsóbb és hosszabb utazás - mint vizsgált kategóriák - a kevesebb utazási tapasztalattal rendelkezőknél intenzívebb motivációként jelennek meg (Paris és Teye 2010). Más szerzők ezt a fajta utazást leginkább menekülésnek tekintik: a kapcsolatoktól, a karriertől, a nagy döntések meghozatalától (Ateljevic és Doorne 2004). A diákok, fiatalabb utazók mellett középkorúak és idősebbek is utaznak ebben a formában, akiket feltehetően valamilyen krízis, fordulópont indít útnak (Riley 1988). Ekképpen az utazás - bármilyen életkorban - egyfajta átmeneti rítusként, liminális ${ }^{10}$ élményként is funkcionálhat az egyes életszakaszok között, valamint kapcsolati krízis (például válás) és számos más feldolgozandó élmény esetén. Hiszen az utazó átmenetiség ideiglenesen tehermentesíthet azáltal, hogy lehetőséget teremt a „normális” életből való kilépésre, a téren és időn kívül helyeződésre (Turner 2002), a megszokott társadalmi kötelékek felfüggesztődésére, és a felemelö, akár flow-élmények (Csíkszentmihályi 1997) által az egyén önmagára találására, ${ }^{11}$ revitalizálására.

\section{Autentikusság és idegenség az utazásban}

A globális áramlások terében (Lash és Urry 1994) a hagyományok és különböző életmódok nap mint nap találkoznak egymással, gyakran tömegkommunikációs médiumok közvetítése által (Giddens 2013). A kulturális sokszínűség, a különbözés, a „más”, az idegen az elmúlt század végétől az emberek meghatározó - gyakran az „autentikusság” eszményében keresett - élménye.

MacCannell 1973-as Staged authenticity [Színpadra állított autentikusság] című írásában úgy vélte, hogy a metropoliszok gyorsan változó képeinek sokasága a turistaélmény része, és ezért is keresi minden turista az autentikusat, amiben a modern ember szent utáni egyetemes vágya nyilvánul meg. Mások szerint az is lehetséges, hogy a posztturista tisztában van azzal, hogy semmi sem autentikus, és ennek tudatában örül a látottaknak (Urry 2002). Továbbá olyan értelmezés is megfogalmazódott (Schleicher 1998: 205), mely szerint míg korábban az autentikusságot föként a vallásban lehetett átélni, addig a szekularizálódó, majd napjaink világában egyre inkább a szabadidős tevékenységekben keressük ezt az élményt, és ezzel „valódi” önmagunk kiteljesítését. ${ }^{12}$ Természetesen ez a vágy látszólag nem jellemző minden utazásra és utazóra, azt hihetnénk, hogy olyan esetekben bukkan fel, amikor a múlt, vagy a más, az idegen megismerése lényeges motiváció.

10 A liminalitás egy létállapotot jelöl, mely során fellazulnak a korábban kialakult struktúrák, az egyén vagy csoport a társadalmi elvárások rendszerén kívül helyezkedik, egyfajta köztes, átmeneti állapotot él meg (Turner 2002).

11 Természetesen az, ahogyan a hátizsákos utazók megélik a saját szabadságukat, a társadalmi kötöttségektől és az otthontól való elszakadást, az olyan viselkedésformákban is megnyilvánulhat, amelyek a környezetük számára nem feltétlenül elfogadhatóak, és zavarhatják is a helyi lakosokat (Ateljevic és Doorne 2004).

12 A turizmus üzleti oldalán fontos eszköz a „hiteles”, „valódi” élmények, látnivalók ígérete, ugyanakkor az utazó motivációjában is gyakran megjelenik ez a vágyakozás, nem függetlenül a másik fél marketingmunkájától. 
Ning Wang (2012) az autentikussággal kapcsolatban újfajta megközelítést javasol a meglévő objektivista és konstruktivista mellé, ami az élmények nagyobb spektrumát képes magyarázni. A tárgyhoz köthető autentikusság helyett Wang egy a tevékenységből eredő egzisztenciális autentikusságról ír, melyben „a Lét potenciális egzisztenciális állapota alakulhat ki a turistáskodás során (...). A turizmus liminális folyamatai aktiválhatják a Lét egzisztenciális állapotát, amely az autentikus élményhez vezet" (Wang 2012: 93-94). ${ }^{13}$ Az egyén a mindennapi, olykor korlátozó szerepekből kibújva, a lélekölő rutinfeladatoktól megszabadulva, a turistaszerepet magára öltve szabadabbnak, spontánabbnak, autentikusabbnak érezheti saját magát és a „valóságot”. ${ }^{14} \mathrm{Ez}$ a fajta autentikusságélmény - ha nem túl merész a párhuzam hasonlít Schulze korábban leírt élményorientáltság-felfogásában a szép élményhez, amennyiben bármely élmény szubjektív értelemben véve különlegessé (autentikussá, széppé) válhat. $\mathrm{Az}$, hogy ez miért történik, magyarázható a Wang elképzelése szerinti szerepeket felfüggesztö liminális folyamatok tevékenységorientáltságával, ugyanakkor talán a lash-i esztétikai reflexió révén a társadalmi kategóriáktól való tudatosabb függetlenedéssel is, mely magukat a létezöket engedi szóhoz jutni (Rényi, Sik és Takács 2014: 25), és teret nyit a szabad, szubjektív értelemtulajdonításnak. Ez az utazás közben átélt tapasztalat általában ideiglenes, utána a turista kész arra, hogy visszatérve alkalmazkodjon a saját társadalmának rendjéhez (Wang 2012).

$\mathrm{Az}$, aki ideiglenesen elhagyja otthonát, egy másik társas dimenzióba kerül, ahol a saját, egyértelmüként megélt kulturális minta kérdésessé válik. Az új térben más vonatkoztatási sémák működnek, még a megközelített csoportról otthonról hozott kép is ütközik a valósággal (Schütz 2004). A tevékenységekben való részvétel ezért egyfajta objektív, megfigyelő távolságtartással történik, amelyet Simmel (2004) a szabadság megnyilvánulásának tekint, mivel az nem függ az ottani megszokásoktól, ami miatt elöítéletektől mentesebben lehet a viszonyokat vizsgálni. Ennek ellenére mégsem ritka az idegen bizonytalansága, szüntelen tudakozódása, és az, hogy nem hajlandó vagy képtelen teljesen lecserélni az otthonról hozott mintáját (Schütz 1984). Az utazónak ez nem is kifejezetten célja, bár ha valóban érdeklödik az adott kultúra iránt, akkor ő is megpróbál minél jobban alkalmazkodni.

Az idegenség, úgy vélem, sokrétű lehet az utazó és a benne lejátszódó lelki és megismerő folyamatok vizsgálata kapcsán. Egyrészt, ha a saját helyzete, társadalmának állapota miatti kiábrándultság, elidegenedés indítja újraértelmező útra, akkor úgyszólván idegenné válik már otthon, a megszokott, ám reflexió tárgyává tett környezetben. Másrészt, amit elutazva tapasztal, az is idegen, ami újfajta értelmezési sémát nyújt, ezáltal reflexivitásra ösztönöz, és ahol ő maga is idegen, mások számára megismerendő vagy elkerülendő jelenség. Harmadrészt pedig hazatérve ismét az idegenséget tapasztalhatja a szokatlanság, és újraértelmezett tájékozódási minta következtében. ${ }^{15}$

13 Ha például a turista kipróbálja a kubai rumbát, a tánc válik az időn kívüli, feszültségmentes valósággá azokban a spirituális és esztétikai pillanatokban, amelyeket a liminalitás teremt, enyhítendő a hétköznapi feszültségeket (Wang 2012: 102).

14 Ebben az értelemben a turista például a gyalogtúrán, a családi tengerparti nyaraláson, az óceánjárón tett körutazáson nem a tárgyszerű autentikusságot keresi, hanem a tevékenységek segítségével egy eszményt: saját autentikus énjét, és az interszubjektív autentikusságot, amelyek még ha a „valóságban” talán illúziók is, a képzeletében, a szubjektív érzések formájában valódiak (Wang 2012).

15 Ahogyan Schütz (2004) hazatérő katonái is csodálkoznak a meg nem értettség miatt, úgy az utazó is eltűnődik a korábbi tapasztalatainak új fényben való megjelenésén. Még ha szemmel látható változás egyik oldalon sem történt, sem az otthon nem ugyanaz a visszatérőnek, sem a hazatérő nem ugyanaz - vagyis szokatlan, idegen már sem önmaga, sem az öt hazavárók számára, legalábbis kezdetben. „A hazatérőnek erőfeszitéseket kell tennie, hogy tevékenységeit újra rutinszerüvé változtassa, és a dolgokhoz, illetve emberekhez füzödö változatlan kapcsolatait reaktiválja" (Schütz 2004: 88). Mindezt úgy, hogy él benne a vágy arra, hogy az idegenben szerzett jó vagy rossz tapasztalataiból, képességekből átemeljen valamennyit a korábbi sémákba, a hétköznapi életébe (Schütz 2004). 


\section{A kutatás kiindulópontja és iránya}

Az utazást tehát az előzőekben bemutatott elméleti megfontolások alapján egy olyan szabadidős tevékenységnek, késő modern cselekvési lehetőségnek, eszköznek feltételezem, amely az elbizonytalanodott identitás és az elveszített ontológiai biztonság (Giddens) újraalkotását lehetővé teheti a szép (Schulze) vagy autentikus élmények (Wang) átélésén keresztül, az esztétikai reflexió (Lash), illetőleg a többszörös idegenséggel (Schütz) való találkozás által. Ha az utazás többször is megismétlődik, akkor az előzőek mellett rutinná vált nem rutin (Giddens, Urry) léte miatt is elmondható ugyanez róla.

Látható ebből, hogy a giddensi teória azon elképzelése a kiindulópont, amely szerint az ember otthon és otthonosan szeretne lenni a világban. A késő modern kor egyedivé válást lehetővé tevő és kényszerítő ereje fogódzók nélkül bénító bizonytalanságba (vagy önhittségbe, ami szintén veszélyforrás lehet) torkollhat. A rutinizált cselekvés, érintkezési sémák, intim kapcsolatok mankót jelenthetnek a hosszú úton, ám ha zavar lép fel, kérdésessé válhat az irány. Az utazás a „semerre” kétségeiből az ismeretlen és új, kalandos „valahol” terepére viheti a maga számára is idegenné (Schütz) vált, a másik helyen idegenként is kezelt és a szokatlan szokásokkal és emberekkel való szembesülés és kapcsolatteremtés létállapotában (Turner) kivételes élményekre (Schulze, Wang) és felismerésekre (Lash) fogékonyabbá váló egyént. Hazatérni (Schütz) a környezeti hatások és azok feldolgozása által kissé átfaragott, lecsiszolt cselekvő fog, aki újra a kormány mögé ülhet, és folytathatja döntésekből álló életét. Persze az utazás is az élete része, föként, hogyha azokat a szeleket választja, amelyek sok (Giddens, Urry) új tengerre elviszik és közben haza is hozzák. Ezen felvázolt feltételezés természetesen csak egy séma, amelynek nem biztos, hogy minden eleme releváns vagy magyarázóerővel bíró az egyes egyének esetében.

A kutatás mindebből kifolyólag arra a kérdéskörre fókuszál, hogy milyen élethelyzetek a katalizátorai a hátizsákos utazásnak mint erre az élethelyzetre adott reakciónak, és hogy ez a válasz mennyiben tekinthető eszköznek, megoldásnak a kialakult problémákra. Azaz, az elemzés során arra teszek kísérletet, hogy rávilágítsak, miképpen valósulhat meg az ontológiai biztonság keresése a bizonytalanság keretei között. ${ }^{16}$

\section{Módszertan és elemzési stratégia}

A személyes élmények, tapasztalatok, érzések, mozgatórugók megismeréséhez, megértéséhez az interjús technika nyújtja a leghatékonyabb alapot, hiszen célja az alany által megélt ellentmondásokkal teli, sokszínű (élet)világ jelentéseinek és az ahhoz füződő kapcsolat mélyebb összefüggéseinek megértése (Kvale 2005). A narratívák identitáskonstrukcióban betöltött jelentős szerepének (Sarbin 2001; Kovács 2007; Vajda és Kovács 2002) tudatában félig strukturált életútinterjúkat készítettem.

16 A hátizsákos utazás maga is sok bizonytalansággal, kockázattal szembenéző cselekvéssort rejthet magában, érdekes paradoxon viszont, hogy az ontológiai biztonság sérülése, azaz egyfajta bizonytalan állapot arra sarkallhatja az egyéneket, hogy a biztonságot e bizonytalan keretek között keressék, mivel ezek a fajta kihívások valószínűleg kontrollálhatóbbnak tünnek az egyén számára az otthoni sok esetben megzabolázhatatlan eseményekhez képest, ráadásul a rutinok felfüggesztése, átalakítása „megújító” hatású lehet. 
Ahhoz, hogy a hátizsákos utazás identitáskonstrukcióban és az ontológiai biztonság helyreállításában elfoglalt szerepe meghatározható legyen, az utazás elötti (motivációk), közbeni (élmények) és utáni (hatások) élethelyzet érzéseinek, gondolatainak, eseményeinek, tapasztalatainak feltérképezésére van szükség. Az utazás előtti élethelyzet vizsgálata az identitás stabilitásának, az ontológiai biztonság meglétének fokáról adhat képet. Ehhez célszerü az első út, az utazások utazó által azonosított motivációjának, várakozásainak feltárása. A minél teljesebb látlelet érdekében az elemzésben a családi háttérről, az utazáshoz való szocializáltságról, a munkahelyröl, a párkapcsolatról, a hétköznapokról is lesz szó mint az útnak indulást potenciálisan befolyásoló tényezőkről. Az utazás közbeni tapasztalatok vizsgálata a jelentős (liminális/szép/autentikus) élmények azonosítását tüzi ki célul. Az utazás utáni életvilág feltérképezése az utazás hatásainak, funkciójának (pl. ontológiai biztonság megteremtése, identitásformálás) megragadására tesz kísérletet. Ahhoz, hogy a hátizsákos utazást az ontológiai bizonytalanság és az identitásválság leküzdésének eszközeként azonosítsuk, úgy gondolom, nem elég a hatásokat megvizsgálni, hanem a kiinduló állapotok és motivációk számbavétele is szükséges ehhez, az élmények feltárása mellett.

Az elemzési eljárás során manuális kódolást alkalmaztam. Az imént bemutatott szempontok szerint újra és újra elolvasva az interjúk szövegeit, azok egészéből raktam össze mindazt, ami közvetlenül vagy közvetetten az adott szempontra vonatkozott. Az alapján, hogy mennyire tünik az utazás az egyén életében segítő funkcióval bíró eszköznek, két utazó élettörténetének tanulságai kerülnek bemutatásra.

\section{Hanna}

Hanna 1979-ben született reálbeállítottságú értelmiségi szülők gyermekeként. A család szellemiségéről fontosnak tartotta hangsúlyozni, hogy azt „materiális és realista életfelfogás” jellemezte. Szülei reál tantárgyakat tanítottak, és mindig volt másodállásuk is, igyekeztek mindent megadni a gyerekeknek, akiknek a tanulás mellett be kellett segíteniük a munkába. A családi klíma ebből is adódóan nem a kitárulkozó intimitás köré szerveződött, viszont nagyobb konfliktusok nem jellemezték a családi légkört - azt leszámítva, hogy a későbbi nyitását a spirituális világnézet felé Hanna nem tudta velük megbeszélni. Ugyanakkor a mindkét szülőt jellemző pragmatikusság az anyagi biztonság megteremtésén kívül nem kedvezett egy viszonylag koherens, lelki biztonságból fakadó (ön)bizalmon alapuló identitás kialakulásának. Habár ezt kompenzálhatta nővére jelenléte, akivel nagyon közel kerültek egymáshoz, és az is, hogy bátorította húgát álmai megvalósítására. A kiinduló kontextust figyelembe véve Hanna életpályaesélyeit tekintve értelmiségi és anyagilag törekvő szülők gyermekeként a regionális és strukturális hátrányok kompenzálása várható. Mindazonáltal a két északkelet-magyarországi kisváros egyikében sem szeretett Hanna élni.

Kompetens hozzáállást tanúsítva, de láthatóan mégsem teljesen céltudatosan, gimnáziumát ő választotta ki: az iskola akkori jó hírneve vonzotta, és egyáltalán nem a fizika tagozat, ahová végül ment. Magas volt az elvárás, amelynek sok tanulás árán, de megfelelt, tehetséggondozó kollégiumban lakott, és jó osztályközösségben teltek ezek az évek, amelyek során kiderült számára, hogy valóban nem érdekli az, amit tanítottak neki. Innen kezdődően, legalábbis az elmeséltek alapján, egyfajta negatív identitás kezd kibontakozni, abban az 
értelemben egyrészt, hogy kevés önbizalma volt ifjú felnőttként, és főként másrészt, hogy könnyebben meg tudta úgy határozni magát, hogy mi az, ami ő nem, amit ő nem szívesen csinálna. A felsőoktatásba kerülését is ez motiválta: „úgy választottam továbbtanulást, hogy mi az, ami nem szeretnék lenni”. A turizmus mint opció megmaradt, így azt végezte el egy észak-alföldi megyeszékhelyen, azonban ismét nem találta megfelelőnek a szerepet. A kevéssé érdekfeszítő tantárgyakat ugyanakkor ismét ellensúlyozta a jó közösség. Két pesti szakmai gyakorlat után a közgazdász vonalat folytatva nemzetközi szakra járt vidéken, ahol sikerült egy kis önbizalomra szert tennie, két bátorító tanárnak köszönhetően.

Később végleg Budapestre költözött, ahol pénzügyi területen kezdett el dolgozni, amiről szintén magától eltávolítóan nyilatkozott: „soha nem akartam”. Majd mintegy magyarázatként a láthatóan kirajzolódó távolságtartásra ezt mondta: „így visszatekintve az én egész életemet az jellemzi, hogy jöttek a lehetöségek és én ezeket elfogadtam, de soha nem gondoltam, hogy én ezekkel fogok dolgozni”. Tehát mintha úgy érezné, vagy úgy szeretné magát bemutatni, mint akivel megtörténnek a jó vagy rossz események, de amelyekre kevés befolyása van. Ez utóbbi szemlélet, az érzés, hogy nem ura az életének, erősen áthatja Hanna élettörténeti elbeszélését, annak ellenére és azzal együtt, hogy legtöbbször mint reflexív cselekvő jelenik meg benne. Folyamatosan pénzügyi területen dolgozott, és tíz év alatt mindig egyre magasabb munkakörbe került, sikert sikerre halmozott. A munka világában is jelen volt Hanna életében a közösség megtartó ereje, időközben viszont, a kétezres évek elején, egy hosszú párkapcsolatának vége szakadt, aminek magyarázatában ismét előkerült az élet rejtélyessége. A szakítás utáni nyáron ült először repülőgépen. Barátnőkkel elmentek tíz napra nyaralni Spanyolországba, ami különleges esemény volt az életében, mintha elkezdődött volna egy új életszakasz. Addig így gondolkodott az életről: „én nagyon sokáig éltem ezt a nagyonnagyon reális énemet, hogy dolgozunk, párkapcsolatban élünk, családot alapitunk”, amelynek már a megfogalmazásából (reális én, realista szülők) is kitünik, hogy a szülői minta erősen áthatotta a gondolkodását. A szakítás nagyon megviselte, és ekkor kezdett a spiritualitás irányába nyitni, melynek hatására belátta, hogy „valamit nem tudsz erőltetni, hogyha egyszer az életedbe ez nincsen beleírva". Az elbeszélést - amelyben, mint már említettem, egyfajta sodródásérzet is megjelenik - átszövi egyfajta spirituális, ok-okozati magyarázatokat nélkülöző láthatatlan erőkre hivatkozó történetszövés, világlátás (pl.: „beleírva”). Ez a spiritualitás - amely hiten és nem ráción alapuló egyszerű összefüggéseken nyugvó világmagyarázattal szolgál, elsősorban biztonságot nyújt -, ahogyan Hanna is megfogalmazta: "feszítette ezt a realista szemléletmódot”.

Közben egyre többet kellett dolgoznia, napi 10-12 órát, hétvégi túlórákkal, „folyamatos feszített tempóban”, a barátokra nem jutott idő, „ez egy ördögi kör lett”. Sikeresnek érezte, érzi magát, mert a munkájában „a reális oldalát nagyon jól tudja használni”. A problémák viszont kumulálódtak: enyhe depresszió, izom- és ideggyulladás és súlyos emésztési problémák érték, és tikkelni kezdett a szeme, azaz vélhetően az ontológiai biztonság gyengülését a teste is jelezni kezdte. Ez volt az a pont, amikor a természetesnek vett gyakorlatokat reflexió tárgyává tette. 2011-ben két hét fizetés nélküli szabadságot és két hét szabadságot kért, és Közép-Amerikába utazott, életében először egyedül, hátizsákkal. Az inspirációt néhány barátja adta, korábban nem hallott a hátizsákos utazásról, így az internetet kezdte el bújni: „aztán fél év alatt annyi információt találtam, hogy neki mertem vágni”. Ez az út, Hanna szerint életének legnagyobb fordulópontja, nagy hatással volt rá, más életérzést tapasztalt. Így fogalmaz: 
Ott ébredtem fel [ismét egy spirituális konnotáció], ott nekem sose voltak kérdéseim (...) és tényleg itthon mindig azt tapasztaltam, hogy nem tudom, merre megy az élet, hogy olyan döcögős, hogy nem látom az utam, hogy merre megy, és ezen az úton meg megtapasztaltam azt, hogy így nincs is A meg B, mert nincsen kérdés, tehát annyira egyértelmúek voltak az utak, hogy a következő nap hova fogok menni, hogy onnan hogy jutok tovább, hogy melyik hostelt választom, soha semmi kérdésem nem volt, mert abszolút tudtam, meg éreztem, hogy mit kell csinálni, és ez volt a legjellemzőbb erre.

Az emberek kedvességét és a szabadságérzést emelte még ki, és a véletlenek (!) nagy szerepét. Ez az élményleírás azt mutatja, hogy olyan tapasztalatban volt része, amilyenben eddig kevésszer: irányítani tudta az eseményeket, még ha egyfajta sorsszerüséget is érzett ebben, és azt tudta, hogy mit szeretne, nem azt, hogy mit nem. A sorsszerüség ez esetben értelmezhető a liminális folyamat beindulásának, ami az egzisztenciális autentikusság megélését vonhatja maga után. Ezen értelmezést erősíti az az élmény, hogy úgy jött „haza arról az útról, mint akit kicseréltek". Ilyen életszemléletbeli változást tapasztalt:

Nem vettem mindent véresen komolyan már, nem azt gondoltam, hogy ennyi az élet, hogy dolgozunk, felkelünk, dolgozunk, lefekszünk, eszünk, próbálunk egy párkapcsolatot kialakítani, meg családunk lesz, hanem így kitágult a világ [...] kevésbé félek, nem gondolom azt, hogy minden kőbe van vésve, hogy véglegesek a dolgok.

Úgy érzi, hogy önbizalma és személyisége is új formát öltött:

Amikor én elkezdtem utazni, akkor ilyen nagyon-nagyon csendes és zárkózott személyiség voltam, sok félelem volt, meg negatív visszajelzés, ami miatt ilyen zárkózott lettem, és az utazás volt az, ami meg így kinyitott, mert hogy amikor ilyen emberekkel utazol, vagy így utazol, akkor mindenki kíváncsi [...] valahogy így adják a szituációk magukat, hogy elkezdesz beszélgetni.

Amikor visszajött, a kollégáinak külön erre a célra lefoglalt tárgyalókban előadásokat kellett tartania az élményeiről, amelyek szintén feltöltötték Hannát, valószínűleg egy kis plusz megbecsültségérzéssel. A munkát folytatta, de azzal, hogy rátalált az utazásra, már volt miért csinálnia, a saját élete feletti kontroll megtapasztalása által egy „igenlő”, nem elkerülésre, hanem tartalomra épülő elképzelés élt benne ezentúl: „tehát azért dolgoztam, hogy utazzak, körülbelül, ez így kompenzálódott".

Az utazás „küldetéssé vált” számára, amit így fejtett ki: „minél több emberrel megismertetni, meg megmutatni azt, hogy milyen sokat tanulsz magadról”, „csomó szembesülés is magaddal, mert nemcsak a szép oldaladdal szembesülsz egy ilyen út során". A barátok őt keresik meg, ha olcsó repülőjegyet szeretnének, vagy ha tanácstalanok, hogy hogyan tervezzék meg az utazásukat, szívesen útbaigazít turistákat, Couchsurfinggel fogad utazókat. A fönökeivel meg tudta beszélni, hogy minden évben elengedjék négy hétre, és a hosszú hétvégéket is általában nagyrészt Európán belüli, olcsó költségvetésü utazással tölti, és legalább kéthetente hétvégén elmegy a természetbe kirándulni, amit ha kihagy, nem érzi jól magát („nincsen természet, nincsenek fák, nem érzed a természetnek azt az erejét"). Tehát az utazás egyfajta rutinná vált Hanna számára, olyanná, amely a szabadságot jelenti neki. Az egészségügyi problémák azonban az új életfelfogás ellenére sem szüntek meg teljesen, és a munka sem lett nyugodtabb, így körülbelül az első hátizsákos út után három évvel otthagyta az akkori munkakörét, és fél évig rehabilitálták. Nagyrészt tünetmentes lett, azonban a gyógytornát vagy a 
jógaórákat nem hanyagolhatja el, és az ételallergiáira is oda kell figyelnie. Szakmai életútja a viszonylag rövid intermezzo után a megkezdett ívében folytatódott, hiszen a pihenés közben egy másik cég egy ugyanolyan munkakörrel kereste meg, mint amiből kilépett. Nyilvánvalóan ez a folytatás sem ok nélkül történt, sejthetö, hogy amit eleinte magától távolinak érzett, az évek során identitásának lényeges alkotóelemévé vált. Ugyanakkor ez a munkahely a korábbihoz hasonlónak bizonyult: „olyan mennyiségü volt a munka, hogy azt nem lehetett ellátni”, és tizennégy hónap után úgy döntött, felmond:

Egyszerüen csak nem akartam tovább ezt csinálni, mert láttam, hogy hova fog vezetni, amit én nem akarok. Mostanra érkezett el oda az életem, hogy annyira különböző a munkám és az, amitől én boldog vagyok, hogy felmondtam, mert nem tudom összeegyeztetni ezt a kettőt [...] hogy ilyen nagyon-nagyon szigorúnak kell lennem a munkahelyemen és be kell tartanom mindent, miközben meg ugye azzal kompenzálok, hogy elutazok és akkor élem meg a szabadságvágyamat meg azt a szabadságérzést. Úgyhogy majd most, most egy új életszakasz kezdődik az életemben.

Az előzményekből tanulva, hittel és reménnyel („biztos vagyok benne, hogy az élet, ahogy eddig is megteremtette [!], most is meg fognak jönni azok a lehetöségek, ami alapján majd így megélek, meg tovább megy az egész") állt az új év elött, az utazás és az időközben elvégzett kineziológia-természetgyógyászat összekombinálásának előzetes tervével. Annak, hogy e tervből mi valósul(t) meg, e tanulmány írója nem tudhatója, ugyanakkor az elemzés szempontjából felmerül a kérdés, hogy vajon a spiritualitás vagy az utazás lehetett nagyobb hatással Hanna életszemléletének alakulására. Mivel az interjú során sem hagyhattam figyelmen kívül, így őt megkérdezve, íme az ő interpretációja:

Mind a kettő, de a spirituális érdeklődésem előtte is megvolt. Viszont az a pozitív életszemlélet és az a vidámság, amit az utazások, meg a sok ilyen típusú ember megismerése kapcsán éltem át, kaptam és építettem magamba, az a spiritualitással nem jött. A pozitív szemlélet megvolt már akkor is, az, hogy nem adom fel, az is, de egy hatalmas nagy boldogságcsomagot kaptam az utazás által.

Némi ellentmondásosság fedezhető fel a magyarázat kapcsán, amely azt mutatja, hogy a két terület láthatóan összemosódik Hanna elképzeléseiben. A leírtak alapján úgy vélem, hogy Hanna életében a spiritualitás egyfajta mindent átható életszemléletté vált, ${ }^{17}$ az utazás pedig inkább a gyakorlati megnyilvánulásokban, a cselekvés szintjén hozott változást, ami akár az említett személyiségváltozásként is értelmezhető.

\section{Zita}

Zita 1983-as születésétől kezdve egy Pest megyei községben él, néhány éve már nem a szülői házban. Nem szeretne Budapestre költözni, ragaszkodik nagyrészt mezőgazdasággal foglalkozó lakosok alkotta szülőfalujához, annak festőinek leírt környezete, „tiszta levegője és a kedves szomszédok” miatt: „nagyon jó megnyugvás hazamenni, itt a pesti forgatag után”. Szülei felsőfokú oktatásban nem vettek részt, édesanyja irodai adminisztrátori munkákat látott

17 Az úti cél megválasztásában is, a nem racionális alapokon nyugvó döntés - ami tekinthető kvázi esztétikai reflexiónak, egy kis spirituális bázissal - számottevő: „igazából így észreveszem a dolgokat és az ilyen üzeneteket (!) az életben”, és azért is szeret egyedül utazni, mert kettesben előfordul, hogy „teljesen más dolgokat vonzotok be (!) egy út során". 
el, édesapja pedig egy mezőgazdasági cégnél dolgozott ágazatvezetőként, és nagy hobbija a dísznövény-kertészkedés volt. Édesanyja mindig túlságosan gondoskodó, féltő, és emiatt szigorú is volt. Zita édesapjának hobbija révén nagyon megszerette a növényeket és az állatokat, ö is szívesen kertészkedik otthon. Kapcsolatuk fiatal korában problémás volt, leginkább azért, mert apja „sokszor az alkoholos pohár után nyúlt”. Viszont szerencsésen alakult a leszokás, és Zita húszas éveire kiegyensúlyozottá vált ez a kapcsolat. A bátyjával szintén rossz kapcsolat alakult ki fiatal korában, de miután ő egy szomszédos országban új életet kezdett, a távolságnak köszönhetően egyre jobban kijönnek egymással. Tehát látható, hogy a családi klímát ellentmondásosság jellemezte, az anyai gondoskodó szeretet és szigor, a meghatározó apai természetszeretet és alkoholproblémák feszültségében, és a bátyja túlzásaival körbevéve. Zita ontológiai biztonságát és önmeghatározását viszont úgy tűnik, mintha ezek kevéssé veszélyeztették volna, annál is inkább, mivel idővel minden probléma orvosolhatóvá vált, valamint iskolai, szakmai életútja is - kontrasztként - egy céltudatos cselekvő képét festi elénk.

Zita általános iskolás éveit is mint a jövője és az idegen kultúrák iránti érdeklödésének, nyitottságának alapjait mutatta be. Középiskolát pedig már céltudatosan választott, mivel a német nyelv vonzotta, amelyet a kulturális ismereteken keresztül mélyebben is megismert, majd tanítani is kezdte az angol mellett, nála fiatalabbaknak. Nemzetközi kommunikáció szakon tanult tovább, majd annál a banknál helyezkedett el, ahol a szakmai gyakorlatát is végezte. Egy öt hónapos másik bankhoz való kitekintést leszámítva tizenkét éve ott tevékenykedik. Több osztályon is dolgozott, és nagyon sokáig nagyon szerette a munkahelyét, viszont a gazdasági helyzet miatt úgy látja, hogy „a bankvilág teljes lejtmenetben van (...) bö egyéve mondom azt, hogy már nem jó, és hogy nem nagyon szeretnék ott maradni”. Ennek a fontolgatásnak a vezetőséghez is híre ment, akik felajánlottak neki három hónap fizetés nélküli szabadságot, amely maradásra is ösztökélte, de már ezt kihasználta, és „most nincs semmi motiváció". Ugyanakkor fontos látni, hogy az ő esetében ez a kiábrándultság nem a munka tartalmával kapcsolatos: „nekem mindig ez volt az álmom, hogy ezt a munkát csináljam", amelyet már hét éve végez. A válság és egy vezetőváltás miatt viszont elmenne onnan: „tudom, hogy ezt akarnám csinálni, csak valószínüleg máshol”.

Zita gyermekkorában az utazás nem volt jellemző szabadidős tevékenysége a családnak. Édesanyja gyermekei születése előtt néhány hónapot eltöltött két országban, ami Zita szerint befolyásolhatta az utazás iránti szeretetét, valamint a hiány is, hogy erre nem volt lehetőségük. „Amikor így lehetöségem lett rá és pénzem, akkor tényleg mindent az utazásra költöttem.” A főiskolai évek alatt megpályázott minden támogatási lehetőséget, dolgozott is, így az első utazásai már ekkor, egy évben valósultak meg: három európai országban járt az aktuális szerelmeivel, és barátokkal. Mint ahogyan a legtöbb utazó, Zita sem hátizsákos utazóként kezdte, ugyanakkor a társaságával nem pusztán tengerparti pihenéssel töltötték a nyaralást, igyekeztek minél többet látni az adott országból. Ezek után „,indult egy olyan, nem is tudom, egy életforma, szenvedély, hogy ahova tudtam, elutaztam mindig az aktuális fiúkkal, baráti társaságokkal, egyre több környéket, egyre több országot, kultúrát fedeztünk fel".

Mindig középkategóriás hotelekben szálltak meg, aztán 2011-ben az akkori barátjával, aki azóta a férje, elindultak hátizsákkal is két hétre felfedezni az Ibériai-félszigetet, hostelekben megszállva. Nagyon sok európai országot bejártak, két éve pedig gondoltak egy nagyot, és elindultak Ázsiába három hétre, hátizsákkal, mert közben nagyon megszerették az utazásnak ezen formáját. Az elmúlt két évük nagyon aktív volt utazás szempontjából, sorra jöttek a távoli desztinációk: Karib térség, Közép-Amerika, Ázsia újabb két és fél hónapra. 
Az utazás módját tekintve Zita - a tipikus hátizsákos utazókkal ellentétben - nagyon ritkán utazott egyedül, szereti megosztani az élményt, leginkább a férjével, mivel teljesen ugyanolyan az érdeklődésük. Emellett Zitáék a hagyományos hátizsákos utazókhoz képest jobban megtervezik az útjukat, legalábbis a szállásfoglalás tekintetében biztosan, de éppen a költségek miatt: „pont mondjuk egy ilyen hátizsákos elméletnek mond ellent az, hogyha te nem foglalsz le időben egy repjegyet olcsón vagy egy szállást időben olcsón”. Zitáék más utazókkal is szeretnek beszélgetni, de főleg a helyiek érdeklik őket:

Mi például nagyon sokszor beszélgettünk így a helyiekkel, hogy ő miből él, mennyit dolgozik, hol tud tanulni, hogy mi mennyibe kerül, hogy hogy’ támogatja a családja őt vagy ő hogy’ támogatja a családot, és ilyen elképesztő dolgokat tudtunk meg, tényleg [...] A legtöbb országról az a benyomásom, hogy nagyon kedvesek az emberek, és hogy ilyen nagyon nyitottak, nagyon barátságosak, nagyon befogadóak.

Zita sokszor használt többes számot az élmények mesélésekor, ami egyrészt nyilvánvalóan arra utal, hogy általában ketten utaznak, másrészt viszont jelzi azt is, hogy férjével egy sorsközösséget vállaló, kölcsönös megértésen és bizalmon alapuló intim kapcsolatot alakítottak ki. Zita számára lényeges az utazások során a kulturális különbségek, a környezet, az emberek hozzáállásának összehasonlítása. Amikor az utazások során szerzett tapasztalatait próbálja átadni másoknak, úgy érzi, hogy értetlenségbe ütközik: „egyszerüen nem tudod áthozni ugyanazt az élményt meg azt az életérzést, ami kint van".

Zita úgy érzi, hogy az utazások hatására sokkal nyitottabb lett, bár ez a változás nem jelent olyan mély személyiségváltozást, amilyenről például Hanna számolt be. Alapvetően érdeklődő volt, mégis most sokkal szívesebben beszélget másokkal és hallgatja meg őket. A másik lényeges változás, hogy sokkal környezettudatosabb lett. Korábban is tudott a klímaváltozásról, azonban eddig nem látta saját szemével a folyók szennyezettségét, a nagyuraknak való kiszolgáltatottságot az őserdők pusztítása kapcsán, a korallzátonyok gondatlanság miatti eltűnését, stb. Most tudatosan figyel az életmódjára, és másokat is próbál erre rávezetni. Az utazás Zita számára a valóság megismerését jelenti: „gondolom, a Mátrixot láttad, és amikor így mondják, hogy most kilépsz a valóságba”. A belváros, ahol dolgozik,

...egy buborék, tehát hogy itt ez a bankárnegyed. Csak diplomás, viszonylag gazdag emberekkel vagyok körülvéve, vagy mondjuk itt vannak a politikusok. Tehát tényleg úgy érzem, hogy ez egy buborék, és tudom, hogy nem ez az igazi élet és nem ez a valóság. És jó, persze, ott van a falu, tehát hogy látom ott is az embereket, bár tényleg csak aludni járok haza. És tudom, hogyha útra kelek, akkor viszont van lehetőségem meglátni az életet.

Zita az életére visszatekintve nem említett egy fordulópontot sem: „abszolút mentem a céljaim felé, és mondhatom azt, hogy amit akartam, úgy nagyrészt, azért ilyen nyolcvan százalékban mindent elértem. Úgyhogy nem volt fordulópont”. Az iskolaváltások és az utazás jelentőségének kapcsán pedig így fogalmazott: „tényleg azt érzem, hogy így kinyílik a világ elöttem". Az elmondottak alapján egy egyenletes tempóban haladó út vázolódik fel: a családi problémák valószínűleg fokozatosan enyhültek, szakmai karrierje céltudatosan ívelt a kívánt irányba, az utazás is apránként, majd egyre intenzívebben jelent meg az életében, és a hátizsákos forma is kimért adagban lépett színre. 


\section{Összevetés és következtetések}

Természetesen nyilvánvaló, hogy a két interjúalany semmilyen sokaságra nézve nem képez reprezentatív mintát, ezért általában véve a hátizsákos utazókról semmiképp sem célszerü következtetéseket levonni. Az életút jellegzetes mozzanatainak feltérképezésével viszont törekedni lehet arra, hogy magyarázzuk az ontológiai biztonságot és az identitáskonstrukciót befolyásoló események és folyamatok hatását az útnak indulásra. A következőkben a már említett elemzési struktúra mentén végigvezetve a két élettörténetet, megjelennek az ellenpontok, és láthatóbbá válik a hátizsákos utazás szerepe is.

Amint láttuk, Hanna a hátizsákos utazás előtt nem volt elégedett a munkájával, a rutinos hétköznapok problémásak voltak számára, ami, azt feltételezem, annak a tünete, hogy az életét olyan nehézség kísérte - feltehetően az intim családi környezet hiánya, a túlzottan pragmatikus környezet -, amely nem kedvezett egy viszonylag koherens, lelki biztonságból fakadó, tartalommal teli, önbizalmon alapuló identitás kialakulásának. A munkával való elégedetlenség központi motívumként lépett elő a vizsgálódás során, hiszen Hanna nem találta megfelelőnek annak tartalmát, ami részben egyedi szocializációs hatásokkal magyarázható, ám egy magasabb vagy átfogóbb szint befolyása itt nyilvánvalóan megmutatkozik. Egyrészt akár magyarázható ez a jelenség a munka marxi értelemben vett elidegenítő hatásával, másrészt pedig a jelen dolgozatban is említett életutak diverzifikálódásával és az önmegvalósítás parancsának való kényszerű megfelelési igénnyel is. Az igény a változatosságra, az újdonságra, bár az ember alapvető tulajdonságának tűnik és végső soron részben az is, a késő modern élménytársadalom társadalmi folyamatainak kényszerű velejárója, ami láthatóan befolyásolja a cselekvők döntéseit. Hanna az utazásban, méghozzá a hátizsákos utazásban látta a lehetőséget arra, hogy aktív, reflexív cselekvőként változtasson a korábbi állapotokon, és megtalálja a világ rendszerében a helyét, amely az otthonosság biztonságában önmeghatározása alapjaként szolgálhat.

Zita abban mindenképpen különbözik Hannától, hogy ő nagyon szerette a munkáját, korai pályaválasztása, céltudatossága a családi nehézségek ellenére is koherens identitással és stabil ontológiai biztonsággal vértezte fel és kísérte végig az életét. Ugyanakkor abban hasonlít Hannához, hogy ahogyan Hanna végső soron idegenkedni kezdett a munkájától, úgy Zita is, bár ő nem a feladatait érezte idegennek, hanem magát a környezetet, ahol nap mint nap dolgozott, a buborékot, ahol nem az igazi élet zajlik, ami nem a valóság. Különbség viszont, hogy Zita életében a hátizsákos világot látás nem váratlan vagy várva várt fordulatként jelent meg, hanem fokozatosan lett ez a preferált utazási forma. Bár Zita életformaként tekint rá, az ö életében nem egy problémára, élethelyzetre való „reakcióként”, hanem „csupán” szabadidős tevékenységként jelenik meg, noha a legfontosabb és a jóllétéhez nélkülözhetetlen hobbiként.

Az utazás közbeni legmeghatározóbb tapasztalatok és élmények valószínúsíthetően öszszefüggésben állnak az utazás motivációjával, azonban nincs determinisztikus összefüggés közöttük, vagyis a vágy nem mindig valósul meg, az élmény nem mindig elégíti ki a vágyat. Utazóink esetében a kiszakadás a hétköznapokból az utazás tényével alapvetően megvalósult, ugyanakkor az ontológiai biztonság megteremtésére irányuló tudattalan, vagy nem teljesen tudatos vágyak rokon élményekkel is találkoztak - mint láttuk, Hanna esetében a „negatív” identitás irányítható, már vágyott eseményekkel, melyek a liminális folyamat bein- 
dulásával az egzisztenciális autentikusság átélését vonhatták maguk után. Az utazás élménye Zita számára is számottevő. A helyiekkel és más utazókkal kialakított kapcsolatok központi jelentőségünek tünnek: Zita a kultúrák, a környezet, a különbözö országokban élö emberek hozzáállásának összehasonlításához jut el általuk, ami a valóság megismerését jelenti számára a bankárnegyedben - mint munkahelyen - tapasztalt buborékhoz képest. Látható ebből, hogy míg Hanna az élményeket inkább emocionális síkon, belső fókusszal önmagára vonatkoztatva igyekszik megtapasztalni, addig Zitánál a szintén intenzív belső élményfeldolgozás inkább kognitív, és a külvilág, a környezet észlelése hangsúlyosabb.

Az utazás hatására Hanna úgy érezte, mintha kicserélték volna, zárkózottsága nyitottsággá alakult, amelynek hátterében az a már kiemelt folyamat állhat, amely során a tagadáson alapuló identitása inkább „igenlö” tartalommal telítődött, valamint a hétköznapi rutinjai megújultak az utazás központi szerepbe helyezésével. Ezekből kifolyólag úgy vélem, hogy a hátizsákos utazás nem a közvetlenül detektálható problémára (pl. munkahelyi, párkapcsolati problémák) adott válasz, hanem egy e mögött meghúzódó, mélyebben gyökerező és hoszszabb ideje fennálló nehézséget, az identitást érintő bizonytalanságot csökkentette. Ezáltal az ontológiai biztonságot annak ellenére is erősítette, hogy némely manifeszt problémára közvetlen megoldás egyelőre nem született. Az utazás Zita életére is hatást fejt ki, noha nem olyan mély személyiségváltozás formájában, mint például Hannánál, de Zita megerősödött környezettudatossága is változás, talán kevésbé személyes jellegü. Az utazás mindkettejük életében rutinná vált, mely Hanna számára a szabadságot jelenti, Zitánál pedig a szenvedélyt, ami által megismerheti a világot.

Arra a kérdésre tehát, hogy milyen élethelyzetek lehetnek a katalizátorai az utazásnak mint reflektív reakciónak, ez a kutatás nem tud kimerítő választ adni, ám jelezni tudja, hogy a kézenfekvő válasz - mint például a rutinokba való belefásultság, a munkával való elégedetlenség - alapvetően nem ad elégséges magyarázatot. Ez alapján arra nézve tehát eredményesnek mondható a vizsgálódás, hogy az utazás jelentőségének, élményeinek és hatásainak az utazó általi szubjektív azonosítása révén ezeket lehetőség nyílt összefüggésbe hozni az életút korai szakaszában és az utazás előtti élethelyzetben felmerülő problémákkal. Azaz az előfeltevés részben empirikus alátámasztást nyert azáltal, hogy bizonyos élmények hatását az identitáskonstrukcióra és az ontológiai biztonságra sikerült azonosítani. Továbbá - ugyan csak egy-egy példával került illusztrálásra itt - úgy tünik, a hátizsákos utazás egyfajta ontológiai biztonságot és egységesebb identitást elősegítő eszközként azonosítható, ugyanakkor abban az esetben is lehet - nem feltétlenül egyfajta segítő funkcióval bíró, de - szemléletformáló hatású, ha az egyén nem egy élethelyzetre és az a mögött megbújó mechanizmusokra való reakcióként indul útnak. Végső soron tehát az utazás egy olyan tevékenység lehet, mely során mindenki a saját ontológiai biztonságának helyreállításához éppen hiányzó elemekkel találkozhat az izgalmakkal és bizonytalansággal teli út során - az élmények sokféleségének lehetőségéből fakadóan.

\section{Hivatkozott irodalom}

Ateljevic, Irena és Stephen Doorne (2004): Theoretical Encounters. A Review of Backpacker Literature. In The Global Nomad. Backpacker Travel in Theory and Practice. Greg Richards és Julie Wilson (szerk.). Clevedon, UK: Channel View Publications. 60-76. 
Bauman, Zygmunt (2001): Identitás és globalizáció. Lettre (42). Interneten: http://epa.oszk.hu/00000/00012/00026/ bauman.htm (letöltve: 2017. április 10.).

Bauman, Zygmunt (2002): Turisták és csavargók. In Globalizáció. A társadalmi következmények. Szeged: Szukits, 121-156.

Bauman, Zygmunt (2004): A zarándok és leszármazottai: sétálók, csavargók és turisták. In Az idegen - Variációk Simmeltöl Derridáig. Biczó Gábor (szerk.). Debrecen: Csokonai Kiadó, 192-206.

Beck, Ulrich (2004): Túl renden és osztályon? Társadalmi egyenlőtlenségek, társadalmi individualizációs folyamatok és az új társadalmi alakulatok, identitások keletkezése. In A társadalmi rétegződés komponensei. Válogatott tanulmányok. Angelusz Róbert (szerk.). Budapest: Új Mandátum, 322-359.

Berger Viktor (2013): A tér problémája Anthony Giddens társadalomelméletében. Replika (82): 25-53. Interneten: http://replika.hu/replika/82-03.

Bódi Jenő (2008): A turistatekintet mögött. Debreceni Disputa (6)5: 4-9. Interneten: http://www.uni-miskolc. hu/ btkvat/doc/pub/ilyes/etnoturizmus.pdf (letöltve: 2017. április 10.)

Cohen, Erik (1972): Toward a Sociology of International Tourism. Social Research (39)1: 164-182. Interneten:http:// www.csus.edu/indiv/s/shawg/courses/182/articles/cohen/cohen.pdf (letöltve: 2017. április 10.).

Cohen, Erik (2004): Backpacking. Diversity and Change. In The Global Nomad. Backpacker Travel in Theory and Practice. Greg Richards és Julie Wilson (szerk.). Clevedon, UK: Channel View Publications, 43-59.

Csíkszentmihályi Mihály (1997): Flow. Az áramlat. A tökéletes élmény pszichológiája. Budapest: Akadémiai Kiadó.

Éber Márk Áron (2008): Túl az élménytársadalmon? Avagy az élménytársadalom másfél évtizede. Szociológiai Szemle 18(1): 78-105. Interneten: http://www.szociologia.hu/dynamic/0801eber.pdf (letöltve: 2017. április 10.).

Franklin, Adrian és Mike Crang (2012): Válságban a turizmus- és utazáselmélet. In Túl a turistatekinteten. A turizmus kritikai és kultúratudományi perspektívái. Bódi Jenő és Pusztai Bertalan (szerk.). Budapest - Szeged - Pécs: Gondolat, 145-168.

Giddens, Anthony (2005): Az intimitás mint demokrácia. Café Bábel (51): 15-26. Interneten: http://www.cafebabel. hu/szamok/sziv/giddens (letöltve: 2017. április 10.).

Giddens, Anthony (2013): Élet a poszttradicionális társadalmakban. Replika (82): 55-96.

Kovács Éva (2007): Interjús módszerek és technikák. In Közösségtanulmány. Módszertani jegyzet. Kovács Éva (szerk.). Budapest - Pécs: Néprajzi Múzeum - PTE BTK Kommunikáció- és Médiatudományi Tanszék, 269-277. Interneten: http://kisebbsegkutato.tk.mta.hu/uploads/files/olvasoszoba/regiokonyvek/kozossegtanulmany.pdf (letöltve: 2017. április 10.).

Kvale, Steinar (2005): Az interjú. Bevezetés a kvalitatív kutatás interjútechnikáiba. Budapest: Jószöveg Mühely.

Lash, Scott és John Urry (1994): Economies of Signs and Space. London: TCS - Sage. DOI: https://doi. org/10.4135/9781446280539.

Luhmann, Niklas (1982): Szerelem, szenvedély. Az intimitás kódolásáról. Budapest: Jószöveg Műhely.

Noy, Caim (2015): Backpacker. In Encyclopedia of Tourism. Jafar Jafari és Honggen Xiao (szerk.). Cham: Springer, 81-83. DOI: https://doi.org/10.1007/978-3-319-01384-8_15 (letöltve: 2017. április 10.).

O’Reilly, Camille Caprioglio (2006): From Drifter to Gap Year Tourist. Mainstreaming Backpacker Travel. Annals of Tourism Research (33)4: 998-1017. DOI: https://doi.org/10.1016/j.annals.2006.04.002 (letöltve: 2017. április 10.).

Paris, Cody Morris és Victor Teye (2010): Understanding Backpacker Motivations. A Travel Career Approach. Journal of Hospitality Marketing \& Management (19)3: 244-259. DOI: http://dx.doi.org/10.1080/19368621003591350 (letöltve: 2017. április 10.).

Puczkó László és Rátz Tamara (2001): A turizmus hatásai. Budapest: Aula.

Rényi Ágnes, Sik Domonkos és Takács Erzsébet (2014): Elemzési szempontok a késő modern társadalmak kordiagnózisához. Szociológiai Szemle 2014/3: 18-60. Interneten: http://www.szociologia.hu/dynamic/renyi_et_al.pdf (letöltve: 2017. április 10.).

Riley, Pamela (1988): Road Culture of International Long-Term Budget Travelers. Annals of Tourism Research 15(3): 313-328. DOI: https://doi.org/10.1016/0160-7383(88)90025-4.

Sarbin, Theodor R. (2001): Az elbeszélés mint a lélektan tő-metaforája. In Narratívák 5. Narratív pszichológia. László János és Thomka Beáta (szerk.). Budapest: Kijárat, 59-77.

Schleicher Vera (1998): Turizmus és regionalitás. In A turizmus, mint kulturális rendszer. Fejős Zoltán (szerk.). Budapest: Néprajzi Múzeum, 203-213.

Schulze, Gerhard (2000): Élménytársadalom. A jelenkor kultúrszociológiája. A hétköznapi élet esztétizálódása. (Részlet az első fejezetből.) Szociológiai Figyelő 15(1-2): 135-157.

Schulze, Gerhard (2003): A Német Szövetségi Köztársaság kulturális átalakulása. In A kultúra szociológiája. Wessely Anna (szerk.). Budapest: Osiris - Láthatatlan Kollégium, 186-204. 
Schütz, Alfred (1984): Az idegen. In A fenomenológia a társadalomtudományban. Hernádi Miklós (szerk.). Budapest: Gondolat, 405-413.

Schütz, Alfred (2004): A hazatérő. In Az idegen - Variációk Simmeltől Derridáig. Biczó Gábor (szerk). Debrecen: Csokonai, 80-90.

Sik Domonkos (2013a): Giddens modernitáselmélete. Identitás és intimitás. Replika (82): 131-144.

Sik Domonkos (2013b): Giddens társadalomelmélete. Társadalomkutatás 31(1): 55-71. DOI: https://doi. org/10.1556/tarskut.31.2013.1.5 (letöltve: 2017. április 10.).

Sik Domonkos (2013c): Lash modernitáselmélete. Jel-kép 3-4. DOI: 10.20520/Jel-Kep.2013.3-4.2 (letöltve: 2017. április 10.).

Sik Domonkos (2014): A klasszikus és késő modernitás egyesített elmélete. Socio.hu 4(4): 150-181. DOI: https:// doi.org/10.18030/socio.hu.2014.4.150.

Simmel, Georg (2004): Exkurzus az idegenröl. In Az idegen - Variációk Simmeltől Derridáig. Biczó Gábor (szerk). Debrecen: Csokonai, 56-60.

Turner, Victor (2002): Liminalitás és communitas. In uő A rituális folyamat. Budapest: Osiris, 145-180.

Urry, John (2002): The Tourist Gaze. (2. kiadás.) London: Sage. DOI: https://doi.org/10.4135/9781446251904.

Vajda Júlia és Kovács Éva (2002): Élettörténet-kutatás a szociológiában. In Forrásvidékek. Társadalomtudományi tanulmányok Némedi Dénes 60. születésnapjára. Felkai Gábor, Molnár Attila Károly és Pál Eszter (szerk.). Budapest: Új Mandátum, 352-366.

Vogt, Jay W. (1976): Wandering. Youth and Travel Behaviour. Annals of Tourism Research 4(1): 25-41. DOI: https:// doi.org/10.1016/0160-7383(76)90051-7 (letöltve: 2017. április 10.).

Wang, Ning (2012): A turisztikai élmény autentikusságának újragondolása. In Túl a turistatekinteten. A turizmus kritikai és kultúratudományi perspektívái. Bódi Jenő és Pusztai Bertalan (szerk.). Budapest - Szeged - Pécs: Gondolat, 90-117.

Welk, Peter (2004): The Beaten Track. Anti-Tourism as an Element of Backpacker Identity Construction. In The Global Nomad. Backpacker Travel in Theory and Practice. Richards és Julie Wilson (szerk.). Clevedon, UK: Channel View Publications, 77-91. 